\title{
Emotional Intelligence on Peer Conformity in Late Adolescence
}

\author{
Endang Mei Yunalia*, Arif Nurma Etika \\ Nursing Science Program, University of Kadiri, Indonesia \\ * endang.mei@unik-kediri.ac.id
}

\begin{abstract}
Self-identity development in adolescents occurs rapidly. This development is marked by the joining of youth in peer groups that can foster peer conformity. Emotional intelligence is needed by adolescents so that adolescents can avoid negative conformity and various bad emotional reactions. The aims of this research is analyze the correlation between emotional intelligence and peer conformity in late adolescence. This correlational analytic study was conducted on 191 respondents at " $X$ " University who were selected using simple random sampling technique. The emotional intelligence was measured using a questionnaire that adapted Goleman's theory, while peer conformity was measured using a peer conformity questionnaire. Emotional intelligence and peer conformity data were analyzed using Spearman Rank test. Spearman Rank test showed p value $0.001<\alpha$ $(0.005), \mathrm{r}$ value $=-0.245$, so there is a correlation between emotional intelligence and peer conformity in adolescents with a negative correlation. That is, the higher level of adolescent emotional intelligence results in lower conformity with peers. This study does not research other factors can increase or decrease peer conformity in adolescents. So that for further research it is necessary to examine the factors that can affect peer conformity, including adolescent self-identity, adolescent self-concept and parental attachment type. The level of peer conformity in late adolescence by paying attention to the internal aspects namely emotional intelligence. Whereas research on peer conformity that has been there, the discussion is mostly done on external factors that can influence the development of peer conformity.
\end{abstract}

Keywords: Adolescent, Conformity, Emotional Intelligence 


\section{STRADA Jurnal Ilmiah Kesehatan}

DOI: $10.30994 /$ sjik.v9i2.502

ISSN: 2252-3847 (print); 2614-350X (online)

Vol.9 No.2 November 2020 Page.1724-1731

\section{BACKGROUND}

Physical and psychosocial changes occur rapidly in adolescence. This change requires adolescents to make adaptations in which the adaptation process can be a stressor in itself for adolescents. Stressors during times of change that occur in adolescents can cause various problems both in the physical and psychosocial aspects of adolescents (Yunalia \& Etika, 2020). Humans are essentially social beings who need each other, influence each other, and have the desire to have social interactions, especially for adolescents (Kuswijayanti, Tagela, \& Setyorini, 2019). The ability to do social interaction during adolescence will be wider and deeper, one of which is interaction with peers. The wider and deeper that adolescents have social ties with peers, the adolescents will take on values that are believed by their friends or groups so that adolescents will have a relationship or attachment with peer groups (Kuswijayanti et al., 2019). This attachment to groups or peers can increase the group's influence on individual adolescents in it (Berndt, 1979).

Along with psychological development, that adolescence is a period where an individual begins to look for identity, so when adolescents have peer groups, generally they will make rules or agreements that apply to the group (Thomas \& Weigert, 2015). The existence of rules that are enforced in the group will require teenagers to follow the rules made in the group. Efforts made by a person to remain able to survive in the group are by taking actions or deeds that are acceptable to the social group (Mcghie, Lewis, \& Hyde, 2012). A high desire to develop social interaction makes adolescents try to follow the rules that exist in their group. The willingness of adolescents to follow the rules adhered to in peer groups is intended so that adolescents avoid social problems with their groups. The willingness and effort of adolescents to always follow every rule in the peer group is called peer conformity (Song, Qinhai Ma, Wu, \& Li, 2012) (Ceilindri \& Budiani, 2016). In addition, adolescents are willing to follow group rules because individual attacks have a tendency to feel stronger if they are well received by the group than when they are called collective mind power (Djendjengi, Utami, \& Susetyo, 2013). However, problems will arise if adolescents always follow group rules that are negative and always justify the rules that apply in their groups (Ningrum, Matulessy, \& Rini, 2019).

The initial survey conducted on a number of students on January 19, 2020, there was a fight between male students of the " $\mathrm{X}$ " faculty and " $\mathrm{Y}$ " faculty students at one of the private universities. After conducting studies on several students, the fight was triggered by two arguments between male students from the " $\mathrm{X}$ " faculty and the "Y" faculty, which started from arguing and making fun of each other. Fellow students from the faculties " $\mathrm{X}$ " and "Y" ended up getting involved in the argument because they thought that cohesiveness in the group was important so that other groups would not dismiss them as insignificant. Based on these studies, it shows that adolescents are still vulnerable to negative peer conformity.

Data from the World Health Organization (WHO) also shows that school brawls that occur among adolescents are still relatively high. Around $36-69 \%$ of male adolescents have been involved in inter-school brawls which are carried out in groups and cases in young girls are $1-32 \%$ (Yunalia \& Etika, 2019). The high number of brawl cases in adolescents can describe the situation about conformity in adolescents, especially conformity that is negative. Peer conformity in adolescents can be positive or negative (Nawar, 2013). Positive peer group conformity, namely the behavior raised by youth groups refers to positive behaviors that support psychological development and the achievement of adolescent growth and development tasks, while negative peer group 


\section{STRADA Jurnal Ilmiah Kesehatan}

DOI: $10.30994 /$ sjik.v9i2.502

ISSN: 2252-3847 (print); 2614-350X (online)

Vol.9 No.2 November 2020 Page.1724-1731

conformity is the behavior raised by adolescent groups which tends to irritate things that are is negative (Indrayana \& Hendrati, 2013). Each of these conformities has different effects, positive peer conformity can have a positive effect on adolescents and their environment, while negative conformity can cause negative effects on adolescents and their environment (Rabintang, 2018).

Adolescents can minimize the development of negative peer conformity by developing good emotional intelligence. Emotional intelligence is the individual's ability to recognize his own feelings or the individual's ability to know the feelings of others properly and accordingly. In addition, emotional intelligence is also the ability to motivate oneself, and the ability of individuals to utilize information sources appropriately before taking action (Chen, Peng, \& Fang, 2016). he ability to think logically in a person can occur if they have high emotional intelligence, so that their emotional intelligence is not easily affected (Esnaola, Revuelta, Ros, \& Sarasa, 2017) and can face every problem they face well (P. Anitha \& Jebaseelan, 2014).

Emotional intelligence makes adolescents able to manage emotions and be able to control themselves so as not to engage in negative behavior, especially the negative influence of peer groups (Arianty, 2018). ntelligence and emotional maturity cause a person to have the ability to manage emotions well and adapt well during relationships with the environment and other people (Dariyo, 2017). Individuals who have good emotional intelligence describe the existence of emotional maturity and good emotional regulation (Mesurado, Vidal, \& Mestre, 2018) which in the end these individuals can express emotions positively and have skills in dealing with experienced stressors including in overcoming problems. Interpersonal (Yunalia \& Suharto, 2020). Based on the above phenomena, a research was conducted on the correlation between emotional intelligence and peer conformity in late adolescents.

\section{METHODS}

This research is a correlational analytic study with a cross sectional approach. The population in this study were students at tertiary institutions " $\mathrm{X}$ " study programs " $\mathrm{A}$ " and "B" totaling 364 students with a sample of 191 respondents who were selected using simple random sampling technique in June 2020. There are 2 measuring instruments used in the study, namely the emotional intelligence questionnaire and the peer conformity questionnaire.

The emotional intelligence questionnaire was adapted from Goleman's theory of emotional intelligence which has been declared valid and reliable in previous research. The validity test of the emotional intelligence questionnaire was tested with the Product Moment formula, then obtained 30 valid questions. Furthermore, based on the reliability test with the Kuder - Richardson formula, the number is 0.7961, meaning that the emotional intelligence questionnaire has a high level of reliability (SADIYAH). Another questionnaire used in the study is the peer conformity questionnaire which has been tested for validity and reliability in previous studies. The validity test conducted was the content validity using expert judgment which was tested with the Gregory table and finally obtained 24 question items for the peer conformity questionnaire. The peer conformity questionnaire reliability test used the Alpha Cronbac formula and the numbers were 0.909> 0.60 meaning the questionnaire was reliable (DEWI, 2015). After the data is collected, the data is processed using the Spearman Rank Test.

This research was conducted in July - August 2020 after obtaining a certificate of ethical acceptance (No. 43 / EC / KEPK-UNIK / 05/2020). The data in this study were 


\section{STRADA Jurnal Ilmiah Kesehatan}

DOI: $10.30994 /$ sjik.v9i2.502

ISSN: 2252-3847 (print); 2614-350X (online)

Vol.9 No.2 November 2020 Page.1724-1731

collected via google form given to respondents. After obtaining the consent of the respondents to participate in the research, the researcher gave the research questionnaire in the form of ggole to the respondents for further collecting and data analysis.

RESULTS

Table 1

Late stage adolescent emotional intelligence $(\mathrm{n}=191)$

\begin{tabular}{lccccc}
\hline \hline Mean & Median & Modus & Std. Deviation & Min & Max \\
\hline 89,4 & 90,00 & 93 & 9,794 & 59 & 118 \\
\hline \hline
\end{tabular}

Table 2

Peer conformity in late adolescence $(n=191)$

\begin{tabular}{cccccc}
\hline \hline Mean & Median & Modus & Std. Deviation & Min & Max \\
\hline 53,66 & 54,00 & 52 & 9,794 & 35 & 67 \\
\hline \hline
\end{tabular}

Table 3

Emotional Intelligence Analysis and Peer Conformity in late adolescence

\begin{tabular}{|c|c|c|c|c|c|c|c|c|c|c|c|c|c|}
\hline \multirow{3}{*}{ Variable } & \multirow{3}{*}{ Category } & \multicolumn{10}{|c|}{ Peer Conformity } & \multirow{3}{*}{$\mathrm{N}$} & \multirow{3}{*}{$\%$} \\
\hline & & \multicolumn{2}{|c|}{ Very high } & \multicolumn{2}{|c|}{ High } & \multicolumn{2}{|c|}{ Moderate } & \multicolumn{2}{|c|}{ Low } & \multicolumn{2}{|c|}{ Very low } & & \\
\hline & & $\mathrm{f}$ & $\%$ & $\mathrm{f}$ & $\%$ & $\mathrm{f}$ & $\%$ & $\mathrm{f}$ & $\%$ & $\mathrm{f}$ & $\%$ & & \\
\hline & Very good & 0 & 0 & 20 & 10,5 & 54 & 28,3 & 20 & 10,4 & 0 & 0 & 94 & 49,2 \\
\hline Emotional & Good & 0 & 0 & 34 & 17,8 & 48 & 25,1 & 7 & 3,7 & 1 & 0,5 & 90 & 47,1 \\
\hline Intelligence & Moderate & 0 & 0 & 3 & 1,6 & 4 & 2,1 & 0 & 0 & 0 & 0 & 7 & 3,6 \\
\hline & Poorly & 0 & 0 & 0 & 0 & 0 & 0 & 0 & 0 & 0 & 0 & 0 & 0 \\
\hline & Total & 0 & 0 & 57 & 29,9 & 106 & 55,5 & 27 & 14,1 & 1 & 0,5 & 191 & 100 \\
\hline & $\begin{array}{l}\text { Sig. (2-tail } \\
\text { Correlation }\end{array}$ & $\begin{array}{l}\text { d) }= \\
\text { Cot }\end{array}$ & $\begin{array}{l}000 \\
\text { cient }\end{array}$ & $-U, a$ & & & & & $x=0$, & & & & \\
\hline
\end{tabular}

Table 3 above shows that almost half of the respondents have a very good level of emotional intelligence with moderate peer conformity. The average value of the respondents' emotional intelligence was 89.34 or included in the good emotional intelligence category, while the mean value of peer conformity was 53.7 or included in the moderate peer conformity category. The statistical test using the Spearman Rank shows the Sig. (2-tailed) $=0.000<\alpha=0.05$ with the Correlation Coefficient value -0.245 which means that there is a negative correlation between emotional intelligence and peer conformity. This means that the higher the emotional intelligence, the lower the peer conformity.

\section{DISCUSSION}

Emotional intelligence is an individual's ability to feel emotions that occur in themselves, and is the ability to describe how individuals express emotional expressions experienced in the form of nonverbal communication (Sulistyowati, Wismanto, \& Utami, 2015). Emotional intelligence is also a condition where an individual is able to control the feelings of himself and others by involving feelings as a basis for thinking and acting (Sarkhosh \& Rezaee, 2014). Other literature explains that emotional intelligence is the ability to recognize, understand, and utilize and control emotions when thinking and acting 


\section{STRADA Jurnal Ilmiah Kesehatan}

DOI: $10.30994 /$ sjik.v9i2.502

ISSN: 2252-3847 (print); 2614-350X (online)

Vol.9 No.2 November 2020 Page.1724-1731

(Kristina, Indriani, \& Niman, 2015). Emotional intelligence in individuals consists of elements of the ability to exercise self-control, motivate oneself, be able to manage stress, be able to control self-desire, the ability to control mood, the ability to show empathy for others, the ability to deal with problems effectively and the ability to establish good interpersonal relationships (Rey et al., 2018).

The emotional intelligence possessed by an individual will enable the individual to recognize himself, self-regulate, be able to empathize, be skilled in socializing and be able to strengthen or motivate himself (Ruiz \& Esteban, 2018). Adolescents with high emotional intelligence will have the ability to exercise self-control so that when they face problems, adolescent emotions can be controlled by themselves and in the end the emotions will become positive emotions (Mesurado et al., 2018). High emotional intelligence will cause individuals to change negative emotions into positive emotions (Wibowo, 2015).

The average emotional intelligence score contained in table 1 is 89.4 or it is included in the good emotional intelligence category. The lowest emotional intelligence score is 59 and the highest is 118 , meaning that there are respondents who have a fairly good level of emotional intelligence and a very good level of emotional intelligence. The difference in the achievement of emotional intelligence in adolescents in the final stage is influenced by various factors, both from internal factors and external factors. Internal factors that affect emotional intelligence are the physical condition and psychological condition of a person, while external factors that affect emotional intelligence include environmental conditions ranging from the influence of upbringing and closeness to people and also the influence of peers (Ristiyadi, Yudiernawati, \& Maemunah, 2017). Internal factors that affect emotional intelligence are a person's psychological situation, one of which is a person's selfconfidence and confidence to be able to control emotions, where emotional control or emotional regulation is a function of emotional intelligence (Shipley et al., 2015).

External factors that affect emotional intelligence are family factors, where the family is the first place for children to recognize other people's emotions. This child's ability to recognize other people's emotions will carry over to the child growing up. A good relationship between children and parents makes adolescents have a tendency to have a good emotional condition in the end (Yunalia \& Etika, 2020). Someone who is close to parents or family also has the ability to increase self-regulated learning (Yuniar \& Darmawati, 2017). Self regulated learning is the ability to control feelings, the ability to understand and analyze situations, and the ability to establish interpersonal relationships. The more self-regulated learning develops due to closeness to parents, the more emotional intelligence will increase (Januardini, Hartati, \& Astuti, 2013).

The concept that explains that emotional intelligence is influenced by external factors, including being influenced by closeness to parents and friends, is in line with research which shows that adolescents who have very good emotional intelligence and good emotional intelligence, almost all have closeness to their parents and state that respondents have close friend. However, for respondents with quite good emotional intelligence, almost half of them have close friends, but respondents stated that their parents are not the closest people to the respondent.

The emotional intelligence possessed by adolescents will help adolescents to control attitudes and behavior to conform to existing social norms. So that adolescents with good emotional intelligence can filter out the negative influences that come from their environment (Chiu, 2010). In general, adolescents have a tendency to follow the rules or norms in their group or what is called conformity, both positive and negative rules. Table 3 


\section{STRADA Jurnal Ilmiah Kesehatan}

DOI: $10.30994 /$ sjik.v9i2.502

ISSN: 2252-3847 (print); 2614-350X (online)

Vol.9 No.2 November 2020 Page.1724-1731

shows the average peer conformity value is $\mathbf{5 3 . 6 6}$ or in the medium conformity category, with 106 respondents $(55.5 \%)$ in the high category and 57 respondents in the high peer conformity category $(29.9 \%)$.

Based on the cross tabulation, it was found that most of the respondents with a good and very good level of emotional intelligence had a moderate level of peer conformity $(55.5 \%)$ and a small proportion had a low level of peer conformity $(14.1 \%)$. The results showed that respondents who have good emotional intelligence do not have high peer conformity. This shows that adolescents with good emotional intelligence are able to involve aspects of thoughts and feelings before implementing the rules in the group. The results of statistical tests show that $\mathrm{p}$ value $=0.000(<\alpha=0.05)$ with the Correlation Coefficient $=-0.245$ which means that there is a relationship between emotional intelligence and peer conformity which is negative. The higher the level of emotional intelligence, the lower the level of peer conformity in adolescents. This shows that in late adolescence, with maturing emotional abilities, adolescents have the ability to choose between negative conformity and positive conformity (Ernawati, 2019).

\section{CONCLUSSION}

There is a relationship between emotional intelligence and peer conformity in late adolescence, with a negative relationship nature. That is, the higher the emotional intelligence, the lower the peer conformity.

\section{REFERENCES}

Arianty, R. (2018). Pengaruh Konformitas dan Regulasi Emosi terhadap Perilaku Cyberbullying di SMK Negeri 15 Samarinda. Psikoborneo, 6(4), 772-783.

Berndt, T. J. (1979). Developmental Changes in Conformity to Peers and Parents. Developmental Psychology, 15(6), 608-616.

Ceilindri, R. A., \& Budiani, M. S. (2016). Harga Diri dan Konformitas dengan Perilaku Bullying Pada Siswa Sekolah Menengah Pertama. Jurnal Psikologi Teori Dan Terapan, 6(2), 64-70.

Chen, Y., Peng, Y., \& Fang, P. (2016). Emotional Intelligence Mediates the Relationship between Age and Subjective Well-Being. The International Journal of Aging and Human Development, 83(2), 91-107. https://doi.org/10.1177/0091415016648705

Chiu, L. K. (2010). University Students' Attitude, Self Efficacy and Motivation Regarding Leisure Time Physical Participation. Jurnal Pendidik Dan Pendidikan, 24, 1-15.

Dariyo, A. (2017). Hubungan Antara Persahabatan dan Kecerdasan Emosi dengan Kepuasan Hidup Remaja Relationship Between Friendship and Emotion Intelligence with Life Satisfaction of Adolescent. Jurnal Psikogenesis, 5(2), 168-179.

Djendjengi, A. O., Utami, S. S., \& Susetyo, D. P. B. (2013). Fanatisme Suporter Persatuan Sepak Bola Makassar Ditinjau dari Kematangan Emosional dan Konformitas. Psikodimensia, 12(1), 121-134.

Ernawati, R. (2019). Influence of Peer Group Conformity on Moral Identity and Penchant for Watching Violent Television Shows on Aggressive Behavior in University Christian Indonesia. Advances in Social Science, Education and Humanities Research, 306(Isseh 2018), 35-37.

Esnaola, I., Revuelta, L., Ros, I., \& Sarasa, M. (2017). The Development of Emotional Intelligence in Adolescence. Anales de Psicología, 33(2), 327-333.

Indrayana, P., \& Hendrati, F. (2013). Hubungan Antara Kecerdasan Emosional Dan Konformitas Kelompok Teman Sebaya Dengan Konsep Diri Remaja. Persona, Jurnal 


\section{STRADA Jurnal Ilmiah Kesehatan}

DOI: $10.30994 /$ sjik.v9i2.502

ISSN: 2252-3847 (print); 2614-350X (online)

Psikologi Indonesia, 2(3), 199-207.

Januardini, L., Hartati, S., \& Astuti, T. P. (2013). Perbedaan Sef Regulated Learning Ditinjau dari Pola Asuh Orangtua pada Siswa Kelas VIII SMP Fransiskus dan SMP PGRI 01 Semarang. Jurnal Psikologi Undip, 12(2), 176-182.

Kristina, S., Indriani, M. Y., \& Niman, S. (2015). Hubungan Kecerdasan Emosional dengan Identitas Diri Remaja di SMA Swasta.

Kuswijayanti, D., Tagela, U., \& Setyorini. (2019). Hubungan Antara Kecerdasan Emosional dengan Konformitas Siswa Kelas VIII SMPN 1 Kandangan, Kabupaten Temanggung Tahun Ajaran 2018/2019. Jurnal Psikologi Konseling, 14(1), 362-372.

Mcghie, A., Lewis, I., \& Hyde, M. K. (2012). The Influence of Conformity and Group Identity on Drink Walking Intentions : Comparing Intentions to Drink Walk Across Risky Pedestrian Crossing Scenarios. Accident Analysis and Prevention, 45, 639-645. https://doi.org/10.1016/j.aap.2011.09.035

Mesurado, B., Vidal, E. M., \& Mestre, A. L. (2018). Negative Emotions and Behavior: The Role of Regulatory Emotional Self-Efficacy. Journal of Adolescence, 64, 62-71.

Nawar, H. (2013). Konformitas dalam kelompok Teman Sebaya (Studi Kasus Dua Kelompok Punk di Kota Makassar).

Ningrum, R. E. C., Matulessy, A., \& Rini, R. A. P. (2019). Hubungan antara Konformitas Teman Sebaya dan Regulasi Emosi dengan Kecenderungan Perilaku Bullying pada Remaja. Jurnal Insight, 15(1), 124-136. https://doi.org/10.32528/ins.v15i1.1669

P. Anitha, \& Jebaseelan, A. U. S. (2014). A Study On Emotional Intelligence Among Adolescent Women College Students At Tiruchirapalli. Indian Journal Of Applied Research, 4(12), 175-177.

Peterson, G. W. (2015). Internalization, Parental Influence and Adolescent Conformity: Compliance and. Youth \& Society, 16(4), 397-420.

Rabintang, T. H. A. (2018). Konformitas Negatif Siswa-Siswi di SMA Negeri 3 Komodo Labuan Bajo.

Rahmayanthi, R. (2017). Konformitas Teman Sebaya dalam Perspektif Multikultural. Journal of Multicultural Studies in Guidance and Counseling, 1(1), 71-82.

Rey, L., Treatment, P., Quintana-orts, C., Treatment, P., Psychology, S., Extremera, N., \& Psychology, S. (2018). Emotional Intelligence and Peer Cyber-Victimisation in Adolescents : Gender as Moderator. Media Education Research Journal, 26(56), 918.

Ristiyadi, W., Yudiernawati, A., \& Maemunah, N. (2017). Hubungan antara Pola Asuh Orangtua dengan Kecerdasan Emosi (EQ) SMPN Dau Malang. Nursing News, 2(1), 555-567.

Ruiz, P., \& Esteban, R. F. C. (2018). Emotional Intelligence, Gender and Family Environment in Peruvian Adolescents. Acta Colombiana de Psicología, 21(2), 200211.

Sarkhosh, M., \& Rezaee, A. A. (2014). How Does University Teachers' Emotional Intelligence Relate To Their Self-Efficacy Beliefs? Porta Linguarum, 85-100.

Shipley, N. L., Jackson, M. J., \& Segrest, S. L. (2015). The Effects of Emotional Intelligence, Age, Work Experience, and Academic Performance. Research in Higher Education Journal, 1-18.

Song, G., Qinhai Ma, Wu, F., \& Li, L. (2012). The Psychological Explanation of Conformity. Social Behavior and Personality, 40(3), 1365-1372.

Sulistyowati, D. A., Wismanto, Y. B., \& Utami, C. T. (2015). Hubungan antara Kecerdasan Emosional dan Optimisme dengan Problem Focused Coping pada 


\section{STRADA Jurnal Ilmiah Kesehatan}

DOI: $10.30994 /$ sjik.v9i2.502

ISSN: 2252-3847 (print); 2614-350X (online)

Mahasiswa S1 Keperawatan Stikes Telogorejo Semarang. Kajian Ilmiah Psikologi, 1(4), 11-18.

Thomas, D. L., \& Weigert, A. J. (2015). Socialization and Adolescent Conformity to Significant Others: A Cross-National Analysis. American Sociological Review, 36(5), 835-847.

Wibowo, M. W. (2015). Hubungan Antara Kecerdasan Emosi , Adversity Quotient dan Efikasi Diri Pada Siswa Kelas XII Madrasah Aliyah Negeri 1 Magelang. Jurnal Psikologi Tabularasa, 10(2), 186-200.

Yunalia, E. M., \& Etika, A. N. (2019). Efektivitas Terapi Kelompok Assertiveness Training terhadap Kemampuan Komunikasi Asertif pada Remaja dengan Perilaku Agresif. Jurnal Keperawatan Jiwa, 7(3), 229-236.

Yunalia, E. M., \& Etika, A. N. (2020). Analisa Kecerdasan Emosional Remaja Tahap Akhir Berdasarkan Jenis Kelamin. Jurnal Keperawatan Jiwa, 8(4), 477-484.

Yunalia, E. M., \& Suharto, I. P. S. (2020). Penurunan Tingkat Perilaku Agresif pada Remaja Putra dengan Terapi Regulasi Emosi. Jurnal Keperawatan Jiwa, 8(3), 361368.

Yuniar, D., \& Darmawati, I. (2017). Dukungan Keluarga Berhubungan dengan Kecerdasan Emosional Remaja. Jurnal Keperawatan Komprehensif, 3(1), 9-17. 